\title{
Pacemaker discomfort induced by the wearing of seat belts
}

\author{
Matthew Wallis*, Iain Todd $†$ and Clive P. Aber
}

Kingston General Hospital, Hull, Humberside, UK.

\begin{abstract}
Summary: A survey was made of 100 consecutive pacemaker recipients to examine problems they may have experienced with seat belts whilst travelling by car, either as drivers (29 patients) or front seat passengers (50 patients). Twenty-one per cent of the drivers and $30 \%$ of the front seat passengers had experienced symptoms, usually of a mild nature. Re-siting of the generator was only necessary in 1 patient and no example of electrode displacement was observed. Suggestions are made as to how this problem might be overcome.
\end{abstract}

\section{Introduction}

Since the wearing of seat belts became compulsory on 1st February, 1983 some patients with permanent pacemakers appear to have encountered problems which relate to the proximity of the pacing generator and the seat belt straps. Symptoms range from discomfort over the site of the pacing unit to frank skin necrosis and ulceration. We therefore decided to study this problem in more detail.

\section{Methods}

One hundred consecutive patients attending the pacemaker clinic at Kingston General Hospital, Hull, were asked to answer questions with respect to the wearing of seat belts when travelling in cars. Note was made of any problems they had experienced around the site of their pacing unit. They were asked to offer a possible explanation, and where possible, to demonstrate the problem in their vehicle. In each case the examining medical officer recorded the amount ('good' or 'poor') of surrounding and/or overlying subcutaneous tissue and the type of pacemaker unit.

\section{Results}

Sixty-eight of the 100 patients studied (52 male and 48

M. Wallis, M.B., Ch.B.; I. Todd, B.Sc., M.B., M.R.C.P.; C.P. Aber, B.Sc., M.D., F.R.C.P.

* Present address: The General Hospital, Steel House Lane, Birmingham

† Present address: Victoria Infirmary, Glasgow

Correspondence: C.P. Aber, Department of Cardiology, Kingston General Hospital, Beverley Road, Hull, North Humberside HU3 1UR.

Accepted: 9 October 1984 female) were seat belt wearers, either as drivers (29) or as front seat passengers (50), 21 patients were both. Nineteen $(28 \%)$ of these 68 patients had experienced symptoms related to the seat belt - mild discomfort, soreness or reddening of the skin adjacent to the pacing generator. Six $(21 \%)$ of the drivers and 15 $(30 \%)$ of the passengers were so affected. In only 1 patient, with pre-ulcerative changes, was it necessary to re-site the unit.

Table I shows the relationship between 'amount' of subcutaneous tissue and the incidence of problems relating to seat belts. A 'good' layer of subcutaneous tissue appears to offer some protective effect $\left(\chi^{2}=3.63, P>0.06\right)$.

The pacemaker type has little bearing on whether problems arise. In particular, the thinner $(11 \mathrm{~mm}$ or less) generators do not seem to award any benefit in this respect $\left(\chi^{2}=0.13, P>0.70\right)$.

The effect of different sites of implantation of the pacemaker generators was difficult to evaluate since $52(78 \%)$ of our 68 patients had their generators positioned in a left subclavian pocket. However, more passengers $(35 \%)$ than drivers $(14 \%)$ had problems with the box in this site (Table II). Units sited in the left axilla ( 7 patients) were almost completely trouble-free.

Table I The relationship between problems with seat belts and the amount of subcutaneous tissue covering pacemaker generator $\left(\chi^{2}=3.63 P>0.06\right)$

\begin{tabular}{lcc}
\hline Subcutaneous fat & Good & Poor \\
\hline Problems & 7 & 12 \\
No problems & 31 & 18 \\
Total & 38 & 30 \\
\hline
\end{tabular}


Table II The relationship between implant site and the incidence of problems with seat belts.

\begin{tabular}{|c|c|c|c|c|c|c|c|}
\hline Implant site & $\begin{array}{c}\text { Left } \\
\text { subclavian }\end{array}$ & $\begin{array}{c}\text { Right } \\
\text { subclavian }\end{array}$ & $\begin{array}{c}\text { Left } \\
\text { axilla }\end{array}$ & $\begin{array}{c}\text { Left } \\
\text { submammary }\end{array}$ & $\begin{array}{l}\text { Right } \\
\text { axilla }\end{array}$ & $\begin{array}{c}\text { Mid } \\
\text { subcostal }\end{array}$ & $\begin{array}{l}\text { Lबी } \\
\text { subcृ্st }\end{array}$ \\
\hline $\begin{array}{l}\text { Passengers (50 patients) } \\
\text { Problems } \\
\text { No problems }\end{array}$ & $\begin{array}{l}12 \\
22\end{array}$ & $\begin{array}{l}1 \\
3\end{array}$ & 5 & 2 & 2 & 1 & $\begin{array}{l}\overrightarrow{\vec{T}} \\
\text { 苂 } \\
\frac{1}{2} \\
\frac{1}{0}\end{array}$ \\
\hline $\begin{array}{l}\text { Drivers (29 patients) } \\
\text { Problems } \\
\text { No problems }\end{array}$ & $\begin{array}{r}3 \\
18\end{array}$ & 1 & 2 & 1 & 1 & 1 & $\begin{array}{l}\overline{\bar{c}} \\
\frac{\Phi}{D} \\
\frac{1}{d}\end{array}$ \\
\hline
\end{tabular}

Two of the 3 patients with generators buried in the anterior abdominal wall found that the lap strap had a tendency to catch under the inferior edge. One patient developed pre-ulcerative changes over the generator in the left subclavian pocket and required re-siting of his pacing unit. Only 2 patients had sought medical advice and both had been given exemption from wearing seat belts by their general practitioners.

As far as we are aware there have been no instances of electrode tip displacement.

\section{Discussion}

At present there is neither informed professional advice available nor legal exemption from the wearing of seat belts for the recipients of permanent pacemakers. Clearly, from our survey, a problem exists since $28 \%$ of this group of patients had experienced difficulty wearing seat belts. In most cases this was 'mild' and amounted to nothing more than an uncomfortable irritation which 'made driving a nuisance', or caused passengers to sit in the rear seat. In some, however, there was clear-cut evidence of local inflammation. Only 1 patient, described above, required resiting of his pacing unit. Some patients had devised various means of padding their generator.

Having recognized the problem can we offer a solution? The site of implantation of the pacemaker generator does not appear to be critical as no site is totally trouble-free for either passenger or driver. The left subclavian site, however, is particularly prone to

\section{References}

AVERY, J.G. (1984). Seat belt success: where next? British Medical Journal, 288, 662.

McDERMOTT, F.T. \& HOUGH, D.E. (1979). Reduction in road fatalities and injuries after legislation for compulsory wearing of seat belts: experience in Victoria and the rest of Australia. British Journal of Surgery, 66, 518. problems in the passenger seat since the shoulder strap is usually in direct contact and, as we have shown, a good pad of fat covering the generator does not always offer sufficient protection. We would expect similar problems for drivers with right subclavian units. The left axilla is most free of problems but even here the shoulder strap can catch under the medial edge of the generator if it is positioned too anteriorly. Similar problems occur on the anterior abdominal wall.

The wide variety of potential implant sites makes it difficult to design a satisfactory seat belt. The only alternative belt currently available is the "harness strap', used in some sports cars. Our direct observations, however, suggest that this may have similar drawbacks.

It therefore appears that the solution may lie with more care and thought being given to the initial implanting of the generator, possibly further out into the axilla. When a unit is in place the alternatives for passengers are either that they, or the manufacturers, construct a protective pad, perhaps incorporated into the strap, or that they retire to the back seat - until rear seat belts become compulsory (Avery, 1984)! For drivers, padding seems to have been successful for the few who have tried it.

We would only favour exemption in very special circumstances in view of the undoubted benefits of wearing seat belts (Avery, 1984; McDermott \& Hough, 1979; Pye \& Waters, 1984). Incidentally, the use of seat belts in our sample had improved from $39 \%$ before legislation to $93 \%$ afterwards.

PYE, G. \& WATERS, E.A. (1984). Effect of seat belt legislation on injuries in road traffic accidents in Nottingham. British Medical Journal, 288, 756. 